\title{
Getting Dress for Local Experience
}

\author{
Usep Suhud $^{1 *}$ Mamoon Allan², Ernita Maulida ${ }^{3}$
}

\author{
${ }^{1}$ Faculty of Economics, Universitas Negeri Jakarta \\ ${ }^{2}$ School of Archaeology and Tourism, University of Jordan \\ 3 Faculty of Engineering, Universitas Negeri Jakarta, Jakarta \\ *Corresponding author. Email: usuhud@unj.ac.id
}

\begin{abstract}
In some tourism destinations, tourists are offered or sometimes required to wear traditional local clothing as part of a tourism gimmick or as part of respect for the place. This idea is not implemented in other appropriate sites. This study explores the attitude of tourists towards wearing traditional host clothing when visiting an indigenous village destination. In this case, the indigenous village is the village of Baduy, a tribe in West Java province that has isolated itself from the changing world. Every day they wear their traditional clothes. The study was conducted in Greater Jakarta, involving tourists selected using the convenient sampling method. Data were collected using an online survey with open-ended questions and were analysed using content analysis. As a result, the participants' attitudes were grouped into favourable, neutral, and unfavourable categories. The favourable attitude has 13 dimensions: experience, respect, mingle, promotion, conservation, uniqueness, appreciation, obedience, support for the local economy, sense of ownership, and agreement.
\end{abstract}

\section{Keywords: Baduy, Ethnic tourism, Textile tourism, Tourism marketing, Traditional cloth}

\section{INTRODUCTION}

In the early thirties, single and employed, a group of travellers travelled from Surabaya, the Province of East Java, Indonesia, to Lasem. The authors found them wearing traditional dresses in the afternoon and taking a photo session for fun. They selected some 'Instagram-able' spots for the background. These tourists hired the traditional clothes for less than USD 2 at the hotel, where they stayed for as long as they wished. Some of them intentionally brought cheongsam, a traditional Chinese cloth, to be worn during selfies. They came for celebrating the 'imlek' (lunar calendar) - the Chinese New Year in February 2019, even though they were not Indonesian Chinese.

Another group consisted of three seniors coming from Jakarta, the capital of Indonesia. Two of them were in their early fifties, another was about 60 , and they claimed they were an active traveller. On the first day of the trip, they already wore traditional clothes, and they loved and had a deep knowledge of textile and other national and global cultural products. Whilst choosing traditional local textile for souvenirs, they addressed many questions about the preparation, process, and consumption of the products to the artisans and owners of the workshops. For these three tourists, travelling to Lasem was like a dream come true.

Lasem is a coastal sub-district in the northern of the Province of Central Java, and it has many stories about acculturation between Chinese and Javanese elements [1]. This acculturation reflects on architecture and the batik industry. Batik is a traditional textile made of mori fabric decorated with meaningful images and colours on it. Indonesia consists of 34 provinces, which in almost every region have a tradition of making traditional textiles that are inherited from generation to generation. Through the Ministry of Education and Culture, 33 kinds of textiles have been designated as intangible cultural heritage, including batik. In the past, men and women in Indonesia had two options in wearing clothes: traditional and western style.

However, nowadays, people generally gradually begin to abandon traditional textiles unless for a special occasion [2]. Lasem batik became more famous after batik was designated as the oral and intangible heritage of humanity by UNESCO in 2009 [3]. The visit of younger and senior tourists to Lasem wearing traditional clothes was intriguing. Withers [4, p. 114] defines cloth as "a generic term embracing all 
textile fabrics and laminar felt". In the tourism field of study, the traditional cloth is mentioned by scholars when discussing ethnic tourism [5], cultural tourism [6], and indigenous tourism [7]. However, based on the authors' observation and participatory observation, the intersection might occur between traditional textile-based tourism and other tourism products, including agricultural, creative, dark, ecological, educational, event, fashion, food, historical, religious, rural, and even urban tourism.

Another time, the (first and third) authors visited a Baduy tribal village in West Java Province. This tribe inhabits two different territorial areas, the Baduy Dalam (inner) and the Baduy Luar (outer). The Baduy Dalam residents continue to maintain the purity of their customs and culture and tend to reject modernization. Even every day they still wear their traditional clothes. On the other hand, the residents of the Baduy Luar have adopted elements of modernization. However, some of them still practice Baduy customs and culture, and some of them still wear their traditional clothes even though the designs and colours are different from the Baduy Dalam clothes. To enter the Baduy Dalam villages, tourists must walk at least two hours along muddy paths and shrubs, up and down hills, crossing river bridges, and crossing rice fields. During the trip, several residents of Baduy Dalam, especially children, teenagers, and young fathers, accompanied them while carrying tourist bags. In general, tourists visit during the weekend, staying one night in the houses of the Baduy Dalam residents. The authors imagine if the tourists during the trip are in the village of Baduy Dalam, wearing the same clothes as those worn by residents. This journey to the Baduy Dalam village inspired the authors to write this study.

This study aims to explore the attitude of tourists towards wearing the traditional clothing of an ethnic group when visiting that ethnic destination, especially the Baduy ethnicity. So far, studies on this topic have not received the attention of tourism researchers or traditional textile researchers.

\section{LITERATURE REVIEW}

The attitude towards wearing local ethnic clothing when visiting a destination is a person's favourable, neutral, and unfavourable opinion about wearing one of the identities in a costume from an ethnicity.

The authors found it difficult to find literature related to tourists' attitudes towards wearing specific ethnic clothing for tourism purposes. The practice of wearing an ethnic costume can be found in several destinations. Nevertheless, few studies present individual attitudes towards ethnic or traditional clothing. Son, Nam, and Kweon [8] investigated and compared two groups of women regarding attitudes toward traditional Korean dresses. The first group is Korean married women. The second group is KoreanVietnamese married women. As a result, they said [8] that "Korean group had more negative attitudes toward Hanbok, the traditional Korean dresses than the Vietnamese group". This difference in attitude can be seen in that Vietnamese women who marry Korean men are more favourable than Korean women and are more appreciative of Korean culture because they are 'foreigners' in Korean cultural circles and their excitement.

In general, prior studies document the role of traditional clothes in a tourism destination that tourists can find and see as:

a. Souvenirs: Locals make handicrafts from traditional textiles, and tourists buy them as a souvenir [7], [9]-[11].

b. Attraction or part of an attraction: Locals wear traditional textile and clothes as they must perform on stage. Besides, traditional textiles and clothes can be found in museums as a collection [5], [12]-[19].

c. Worn by locals as daily clothes: In some areas, locals wear traditional textile and clothes for daily purposes [20]-[22].

d. Used as a ritual: Traditional textile connects humans with the Creator, environment, and society in a ritual [23]-[25].

e. Worn by hotel or restaurant employee as uniform: Hotel employees served guesses while wearing traditional clothes. This is observed by the authors of this current study.

f. Worn by tourist as a medium: Tourists took a selfie while wearing traditional clothes in a tourism destination. This is addressed by this current study.

Considering the roles of traditional clothes above, in reality, we do not abandon traditional clothes amid the fast fashion industry that continues to innovate.

\section{METHODS}

This study was conducted in Greater Jakarta by involving tourists and knowing the existence of the Baduy tribe. Participants were selected using the convenient sampling method. Those willing to be involved in this study were sent a link to a 
questionnaire with questions about attention, interest, search, action, and sharing related to wearing traditional Baduy clothing during their visit to Baduy. In addition, they were also asked for their opinion about wearing traditional Baduy clothes during their visit to Baduy. This questions were adapted from a study that Suhud et al. [26] has carried out. The data were processed using the content analysis method.

\section{RESULTS AND DISCUSSION}

\subsection{Participants}

This study involved 508 participants consisting of 166 men $(32.7 \%)$ and 342 women $(67.3 \%)$. Regarding age, 320 participants $(63 \%)$ were less than 20 years old, 134 participants were between 20 and 24 years old, and 54 participants (10.6\%) were over 24 years old. Furthermore, 463 participants $(91.1 \%)$ admitted to unmarried, while 45 participants $(8.9 \%)$ were married. Next, about occupational status, 107 participants $(21.1 \%)$ said that they were employed, 376 participants $(74 \%)$ were unemployed, 23 participants $(4.5 \%)$ were self-employed, and two participants $(0.4 \%)$ were retired.

Table 2. Profile of participants

\begin{tabular}{|c|c|c|c|}
\hline \multicolumn{2}{|l|}{ Profile } & Freq. & $\%$ \\
\hline \multirow[t]{3}{*}{ Sex } & Male & 166 & 32.7 \\
\hline & Female & 342 & 67.3 \\
\hline & Total & 508 & 100.0 \\
\hline \multirow[t]{3}{*}{ Age } & $<20$ & 320 & 63.0 \\
\hline & $20-24$ & 134 & 26.4 \\
\hline & $>24$ & 54 & 10.6 \\
\hline \multirow[t]{2}{*}{ Marital Status } & Unmarried & 463 & 91.1 \\
\hline & Married & 45 & 8.9 \\
\hline \multirow{4}{*}{$\begin{array}{l}\text { Occupational } \\
\text { Status }\end{array}$} & Employed & 107 & 21.1 \\
\hline & Unemployed & 376 & 74.0 \\
\hline & Self-employed & 23 & 4.5 \\
\hline & Retired & 2 & 0.4 \\
\hline \multirow{5}{*}{$\begin{array}{l}\text { Educational } \\
\text { level has been } \\
\text { completed }\end{array}$} & $\begin{array}{l}\text { Less than high } \\
\text { school }\end{array}$ & 35 & 6.9 \\
\hline & Diploma & 26 & 5.1 \\
\hline & Postgraduate & 3 & 0.6 \\
\hline & Undergraduate & 69 & 13.6 \\
\hline & High school & 375 & 73.8 \\
\hline
\end{tabular}

Thirty-four participants (6.7\%) admitted that they were adventurers. Furthermore, 399 participants $(78.5 \%)$ said they had visited a Baduy village before. In addition, 307 participants $(60.4 \%)$ claimed to be interested in visiting Baduy villages in the next three months.

The participants were asked: "If you had the opportunity to go on a tour with the above concept, would you post a selfie while wearing your traditional Baduy outfit on your social media accounts?" There were 405 participants $(79.7 \%)$ who stated that they would share selfie photos on social media.

\subsection{Attitude toward Wearing Baduy Traditional Cloth during Visit}

Table 2 presents tourists' attitudes toward wearing traditional cloth at a tourism destination. In total, there were 508 participants involved in this study. Four hundred fifty participants $(88.6 \%)$ had a favourable attitude. There were also 29 participants $(5.7 \%)$ who had a neutral attitude. While the rest $(4.9 \%)$ were unfavourable, and four participants did not show an apparent attitude. The following are examples of each respondent's attitude.

Table 1. Role of traditional clothes in tourism destinations

\begin{tabular}{l|c|c}
\hline Attitude & Frequency & Percent \\
\hline Favourable & 450 & 88.6 \\
\hline Neutral & 29 & 5.7 \\
\hline Unfavourable & 25 & 4.9 \\
\hline NA & 4 & 0.8 \\
\hline Total & 508 & 100.0 \\
\hline
\end{tabular}

a. Agreement. The agreements of participants to the concept of the tour are as follows.

"It's okay because there is nothing wrong with tourists wearing the traditional cloth of the Baduy tribe."

"It's okay if you want to wear Baduy traditional clothes, that way, tourists or we are likened to respecting the Baduy tribe or people by wearing Baduy traditional clothes."

b. Appreciation. Some participants expressed their appreciation through the following examples of statements. 
"I agree because I appreciate the Baduy more with the same clothes as they like and more attached to their culture."

"In my opinion, this is a good idea. Besides, we learn to respect the culture, and we also learn to love the culture and characteristics of the area."

"Good concept. After all, Baduy people want to maintain their concept of life without being influenced by the outside world. Naturally, we should follow them."

c. Mingle. The participants stated that by wearing the traditional clothes of the hosts they visited, they felt a particular affinity.

"It is very interesting because by wearing traditional Baduy clothes, we become closer to the Baduy community."

"It's very interesting because you can directly interact with the natives."

"The concept is very good and can make the relationship between tourists and natives closer."

"Following the customs and customs of the Baduy tribe."

"To blend in with the tribal community."

d. Conservation. Several participants stated that wearing traditional host clothing is a form of conservation.

"It's a good idea so that the customs will still exist, many Baduy people are not interested, so if there is a tour like this, it would be better how just to attract attention and persuade people to be interested in joining this tour."

"I think that was great, and it will be a preservation of Indonesian culture."

"This is good because it can preserve Baduy culture."

"(I) agree, so that the Baduy's traditional clothes are sustainable."

"(It's) good because it preserves the original Baduy culture."

"(I) agree because this is one of the local wisdoms that must be preserved and preserved."

e. Cool. Participants indicated that wearing traditional host clothing was cool.
"Cool, because I can get to know the culture more deeply."

"That's cool."

"So cool and interesting."

f. Experience. Participants thought about getting the experience of wearing traditional Baduy clothes when visiting Baduy villages. The following are examples of their statements.

"Very interesting, because with that we will feel the sensation."

"(It's) very interesting, because we can feel the sensation of being a Baduy community,"

"It's exciting trying to wear Baduy clothes."

"This concept is good to apply so that tourists can feel the daily life in Baduy, namely about the clothes they wear."

"Tourists can feel how the Baduy people dress and are more united with the tribes there,"

"Good, because it will be more felt and blended in with the people there."

g. Obedience. Examples of obedient attitudes to the game's rules can be seen from the following statements.

"It should be recommended to wear Baduy traditional clothes when we are there because we have to respect and cultivate Baduy customs."

"If we are advised to wear traditional clothes, it doesn't matter. Maybe the tradition there has to wear traditional clothes."

"Yes, if that's the concept, the tourists who follow the tour must carry it out."

"Always obey the local regulations."

"It's better to follow the customs that apply there."

h. Promotion. The following are examples of participants' opinions who presented that wearing traditional local clothing could be used as a promotional event.

"Very good, because by telling tourists to wear Baduy traditional clothes, we are promoting (the) Baduy traditional clothes."

"It's excellent to introduce Baduy culture as well as give a moral impression to the visitors, and it 
can open the view that humans can live quite simply with primitive things in this modern era."

"Introducing culture."

"It's pretty good because we can introduce our culture more deeply."

i. Respect. The following statements are the attitude of participants who respect wearing local traditional clothes when visiting a destination, especially Baduy.

"I think it is very honourable to be able to wear traditional Baduy clothes, and this is aimed at respecting the original Baduy people."

"Good, because it's the same as respecting the residents there as hosts."

"Good, because (this) respects the Baduy tribe by wearing the same clothes as the Baduy people, and (this) looks interesting and amazed. And makes us like a resident of the Baduy tribe, even if only for a moment."

"(It's) good. (It will) appreciate the Baduy customs more when visiting there."

j. Support for Local Economy. The following are statements from participants that present their support for the economy of the Baduy community.

"I agree that the clothes produced by the Baduy people can be used as an economic field for the people."

"It's very good because it can revive the economy of the people there."

"Good, but there must be rental of the traditional clothes, and it is better to use a rate that is sufficient for tourists."

"It's okay, but it's better if tourists can buy (traditional clothes) so that in the Baduy village there is a buying and selling transaction process."

k. Understanding. The following statements represent the understanding theme.

"I think it's good so that tourists know that there are many customs in Indonesia, not just one. And it can be used as a means to promote our culture."

"We can know what the Baduy's traditional clothes look like and can be used as a cultural heritage in this modern era."
"That's a good thing because that way you can know what their culture is like."

"Because, with this, we can get to know the Baduy tribe and can introduce Baduy traditional clothes."

"To introduce the cultural identity of the Baduy tribe."

"Good, because I can recognize and wear Baduy clothes."

1. Uniqueness. Some participants thought that wearing traditional clothes from local hosts was unique.

"Very unique and interesting."

"A unique journey by feeling part of the tribe, creating a sense of ownership of the tourist attractions, interesting."

"It's okay. It's unique. You just have to distinguish between the original Baduy clothes and the tourists, so you can tell which ones are natives or tourists."

"I really agree with the concept that was made because wearing typical clothes from the Baduy tribe makes us seem to be one with the Baduy tribe and closer to them."

The following are examples of participant answers showing a neutral attitude towards wearing local ethnic clothing when visiting a destination.

The following examples demonstrate an unfavourable attitude towards wearing local ethnic attire when visiting a destination.

\subsection{Discussion}

In some countries, a traditional dress can become a national costume, and the use of this clothing is still maintained even though it has changed its function in some places [27]. One role that continues to grow is for tourism purposes, where there is an opportunity for economic improvement for the occupation of a destination. The traditional costume was related to social class and social identity long ago [28]. Today, traditional clothes are rented and sold to be enjoyed in tourist destinations for nostalgia [29] and selfie.

Participants were positive about wearing local traditional clothes when visiting a destination. This attitude is driven by an agreement that this idea is right and good. This attitude is also based on appreciation for this unusual idea. So far, when tourists engage in 
ethnic tourism products, they still wear their city clothes. But with the idea of wearing local clothes, they feel more mixed with the hosts, as if without distance [30]. The participants thought that wearing local traditional clothes was also a form of their support for conserving traditional fabrics and clothing so that the wearing could continue [31].

Furthermore, wearing traditional clothes while visiting a destination is cool and attractive. That way, they can also feel a new experience as a host [32]. In addition, the participants also thought that this was a form of their compliance with local regulations. They consider that wearing local traditional clothes is a form of obedience and respect for the host and a medium of learning to understand the local culture better [30], [33].

The tourists will take pictures and upload their photos to social media [32]. Furthermore, the more spread out the images, the greater the potential for potential tourists to get information and be interested in visiting the destination. If they visit, there will be transactions that can improve the economy of the people visited. In addition, the participants considered that wearing local traditional clothes was a form of promotion.

\section{CONCLUSION}

This study explored the attitude of tourists towards wearing traditional host clothing when visiting an indigenous village destination. The participants' attitudes were grouped into favourable, neutral, and unfavourable categories. The favourable attitude consists of experience, respect, mingle, promotion, conservation, uniqueness, appreciation, obedience, support for the local economy, sense of ownership, and agreement. The findings from this study deepen the study of indigenous tourism, textile tourists, and marketing tourism.

The authors are aware of several limitations of this study. First, data collection used an online survey with open-ended questions, and the authors did not have the opportunity to dig deeper and confirm any answers that were not clear.

The findings of this study broaden the topic of tourism marketing, especially for ethnic tourism. Baduy tribe represents ethnic groups that can attract tourists because they have cultural characteristics. Other ethnic groups in Indonesia and other countries can also apply this approach. This study also highlights how traditional textiles are conserved and marketed. Traditional textiles are a national identity. Furthermore, traditional textiles are a national identity.
Continuing to make traditional textiles exist will maintain the identity, and the indigenous people's economy can continue to run.

The authors suggest that future studies collect data using other approaches, such as in-depth interviews and focus groups, to get a more appropriate depth. In addition, quantitative studies are also suggested to obtain confirmation of the creation of dimensions of tourist attitudes towards wearing traditional host clothing when visiting tourism destinations.

\section{AUTHORS' CONTRIBUTIONS}

Three authors wrote this article. The first author is responsible for article writing, data collection, and data processing. In addition, the second author contributed to completing the introduction and literature review, including proofreading. The third author contributed to data collection and analysis.

\section{ACKNOWLEDGMENTS}

This study is part of a tourism village research project funded by the Ministry of Education and Culture, Republic of Indonesia.

\section{REFERENCES}

[1] D. Darmawan, "The influence of Javanese culture in ancient houses in Lasem," in International Cofnerence of Urban Heritage and Susainable Infrastructure, 2016, p. 185.

[2] N. Huttasin, "Perceived social impacts of tourism by residents in the OTOP tourism village, Thailand," Asia Pacific J. Tour. Res., vol. 13, no. 2, 2008, pp. 175-191.

[3] A. Wahyu, Chic in batik. PT Penerbit Erlangga Mahameru, 2012.

[4] J. C. Withers, "Textile terms and definitions," in Aslib Proceedings, 1952.

[5] A. C. Bunten, "More like ourselves: Indigenous capitalism through tourism," Am. Indian Q., vol. 34, no. 3, 2010, pp. 285-311.

[6] K. G. Tomaselli, "Psychospiritual ecoscience: The Ju/'hoansi and cultural tourism," Vis. Anthropol., vol. 12, no. 2-3, 1999, pp. 185195.

[7] D. K. Müller and R. Pettersson, "Access to Sami tourism in northern Sweden," Scand. J. 
Hosp. Tour., vol. 1, no. 1, 2001, pp. 5-18.

[8] J. A. Son, Y. J. Nam, and J. H. Kweon, "Study on clothing life of Korea-Vietnam multicultural families-focus on clothing behaviors and attitudes toward traditional dresses," J. Korean Soc. Costume, vol. 63, no. 6, 2013, pp. 127-139.

[9] C. Flacke-Neudorfer, "Tourism, gender and development in the third world: A case study from northern Laos," Tour. Hosp. Plan. Dev., vol. 4, no. 2, 2007, pp. 135-147.

[10] S. Gössling and U. Schulz, "Tourism-related migration in Zanzibar, Tanzania," Tour. Geogr., vol. 7, no. 1, 2005, pp. 43-62.

[11] J. Warner, "North Cyprus: Tourism and the challenge of non-recognition," J. Sustain. Tour., vol. 7, no. 2, 1999, pp. 128-145.

[12] R. Bandyopadhyay, "The perennial Western tourism representations of India that refuse to die," Tour. An Int. Interdiscip. J., vol. 57, no. 1, 2009, pp. 23-35.

[13] L. Hiwasaki, "Ethnic tourism in Hokkaido and the shaping of Ainu identity," Pac. Aff., 2000, pp. 393-412.

[14] A. Hüncke and S. Koot, "The presentation of Bushmen in cultural tourism: Tourists' images of Bushmen and the tourism provider's presentation of (Hai//om) Bushmen at Treesleeper Camp, Namibia," Crit. arts, vol. 26, no. 5, 2012, pp. 671-689.

[15] A. Kirkegaard, "Tourism industry and local music culture in contemporary Zanzibar," Same other Negot. African identity Cult. Prod., 2001, pp. 59-76.

[16] S. R. Pitchford, "Ethnic tourism and nationalism in Wales," Ann. Tour. Res., vol. 22, no. 1,1995 , pp. 35-52.

[17] T. Sofield and F. M. S. Li, "Indigenous minorities of China and effects of tourism," in Tourism and Indigenous Peoples, Routledge, 2007, pp. 283-298.

[18] P. L. Van den Berghe and C. F. Keyes, "Introduction tourism and re-created ethnicity," Annals of tourism research, vol. 11, no. 3. Elsevier, 1984, pp. 343-352.
[19] E. Wiley, "Romani performance and heritage tourism: the pilgrimage of the gypsies at Les Saintes-Maries-de-la-Mer," TDR/The Drama Rev., vol. 49, no. 2, 2005, pp. 135-158.

[20] S. Braman and F. A. Amazonia, "Practical strategies for pro-poor tourism TROPIC Ecological Adventures-Ecuador,” 2001.

[21] W. G. Feighery, "Tourism and selforientalism in Oman: A critical discourse analysis," Crit. Discourse Stud., vol. 9, no. 3, 2012, pp. 269-284.

[22] D. Theodossopoulos, "Emberá indigenous tourism and the trap of authenticity: Beyond inauthenticity and invention," Anthropol. Q., 2013, pp. 397-425.

[23] P.-A. Addo, "Forms of transnationalism, forms of tradition: Cloth and cash as ritual exchange valuables in the Tongan diaspora," in Migration and Transnationalism. Pacific Perspective, H. Lee and S. T. Francis, Eds. Canberra: ANU Press, 2009, p. 43.

[24] K. Klein, The unbroken thread: conserving the textile traditions of Oaxaca. Getty Publications, 1997.

[25] A. Murwanti, "Mitoni, lurik and the stitches of lament," 2013.

[26] U. Suhud, T. Tarma, and E. Maulida, "Authenticity of fourth world country tourism: A case of Baduy, Indonesia," Int. J. Innov. Creat. Chang., vol. 10, no. 9, 2019, pp. 133153.

[27] S. M. Minhus and L. Huie, "The tendency of traditional costume at heritage festival for cultural revival," SAGE Open, vol. 11, no. 2, 2021, p. 21582440211016904.

[28] T. Maxmudjon, "The figurative expression of the composition of costume," Innov. Technol. Methodical Res. J., vol. 2, no. 10, 2021, pp. 38-42.

[29] C. Shaw, "Introduction: Television and nostalgia now," J. Pop. Telev., vol. 9, no. 3, 2021, pp. 287-291.

[30] A. Hamzah, "Malaysian homestays from the perspective of young Japanese tourists: The quest for Furusato," in Asian tourism: Growth and change, Routledge, 2007, pp. 213-228. 
[31] H. W. Guang, "Uyghur traditional folk songs and costumes conservation in Gansu Province," Tehlikedeki Diller Derg., vol. 5, no. 8, 2006, pp. 53-66.

[32] K.-Y. Lee and H. Lee, "Traditional costume experience at a cultural heritage festival," Tour. Manag. Perspect., vol. 32, 2019, p. 100555.

[33] H.-C. Han, "Moving from cultural appropriation to cultural appreciation," Art Educ., vol. 72, no. 2, 2019, pp. 8-13. 